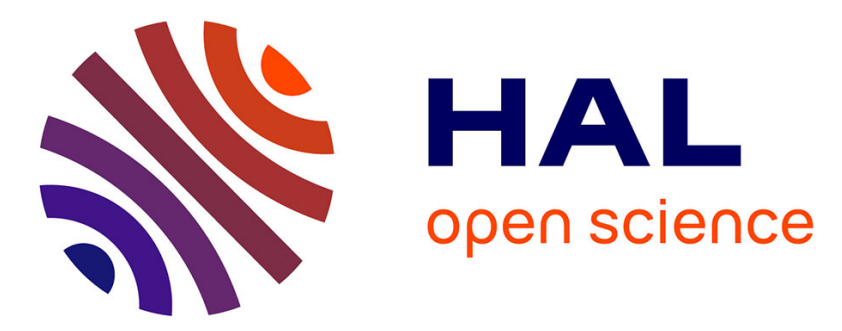

\title{
Biological secondary contributors to osteoporosis in fractured patients, is an early systematic assay relevant?
}

Pierre-Emmanuel Cailleaux, David Biau, Philippe Leclerc, Philippe Anract, Christian Roux, Karine Briot

\section{- To cite this version:}

Pierre-Emmanuel Cailleaux, David Biau, Philippe Leclerc, Philippe Anract, Christian Roux, et al.. Biological secondary contributors to osteoporosis in fractured patients, is an early systematic assay relevant?. Joint Bone Spine, 2019, 86, pp.777 - 781. 10.1016/j.jbspin.2019.03.009 . hal-03489005

\section{HAL Id: hal-03489005 https://hal.science/hal-03489005}

Submitted on 21 Dec 2021

HAL is a multi-disciplinary open access archive for the deposit and dissemination of scientific research documents, whether they are published or not. The documents may come from teaching and research institutions in France or abroad, or from public or private research centers.
L'archive ouverte pluridisciplinaire HAL, est destinée au dépôt et à la diffusion de documents scientifiques de niveau recherche, publiés ou non, émanant des établissements d'enseignement et de recherche français ou étrangers, des laboratoires publics ou privés.

\section{(ㄷ)(1) $\$$}

Distributed under a Creative Commons Attribution - NonCommerciall 4.0 International 
Biological secondary contributors to osteoporosis in fractured patients, is an early systematic assay relevant?

Pierre-Emmanuel Cailleaux ${ }^{1,6}$, David Biau ${ }^{2,4,5}$, Philippe Leclerc ${ }^{2}$, Philippe Anract ${ }^{2,4,5}$, Christian Roux $^{3,4,5}$, Karine Briot ${ }^{3,4}$

1. Geriatrics Department, Louis-Mourier Hospital, APHP, 92701 Colombes cedex, France

2. Orthopedics Department, Cochin Hospital, APHP, 75014 Paris France

3. Rheumatology Department, Cochin Hospital, 75014 Paris, France

4. INSERM U1153, 75014 Paris France

5. Paris Descartes University, 75006 Paris, France

6. Paris Diderot University, 75013Paris, France

\section{$\underline{\text { Author for correspondence }}$}

Briot Karine,

Rheumatology Department, Cochin Hospital

27 rue du Faubourg St Jacques, 75014 Paris, France

Email : karine.briot@aphp.fr

Phone number +33 1584125 84, Fax number +33158411370 


\section{Abstract}

Objective: To evaluate the prevalence of biological abnormalities leading to secondary osteoporosis in recently fractured patients.

Methods: Adults older than 50, hospitalized for a nonvertebral fracture from July 2015 to October 2016, were assessed for bone fragility contributors in the Orthopedics Department. Bone mineral density (BMD) measurements and Vertebral Fracture assessment (VFA) were performed within 3 months. We assessed the prevalence of biological abnormalities in all the patients with recent fracture and in subgroups.

Results: Among 439 hospitalized patients for non-vertebral low trauma fracture, 372 had biological tests (285 women, mean age $77.5 \pm 13$ years) and 353 (94.6\%) had at least $\geq 1$ biological abnormality, most frequently vitamin D insufficiency $(<75 \mathrm{nmol} / \mathrm{L})(80 \%)$. Hypercalcemia was found in $22(7.7 \%)$ patients, explained by possible primary hyperparathyroidism in 6 cases, and by the other causes of hypercalcemia including postoperative low albumin. A high PTH level was observed in 64 (20.8\%) patients.. We found 3 monoclonal bands. Results were similar in patients with and without vertebral fracture or osteoporosis. Finally, many biological abnormalities can be explained by the postoperative context (low TSH, hypogammaglobulinemia, low albumin, low alkaline phosphatase) and need a control.

Conclusion: This study performed in patient with recent low trauma non-vertebral fractures showed that $94.6 \%$ of patients had at least one contributor to bone fragility, which was the vitamin D insufficiency in most of cases. We found a high proportion of biological abnormalities which require additional explorations but most of them can be explained by the postoperative context.

Key words: fracture, fracture liaison service, osteoporosis, secondary cause of osteoporosis. 


\section{Introduction}

In patients with low trauma fractures, searching for secondary contributors to osteoporosis is recommended, in order to identify curable causes (1-3). Performing tests is recommended (4) but there are various accepted manners worldwide on laboratory tests that could be performed (5-8). However prevalence of abnormalities leading to secondary osteoporosis in different studies of osteoporotic patients varied greatly from 3 to 55\% (9). Age and gender can explain the differences, and secondary osteoporosis is known to be more frequent in men than in women $(10,11)$. The causes of secondary osteoporosis may be different for cortical or trabecular sites of fractures, and whether osteoporosis is defined by bone mineral density only, and/or the presence of fractures (12-18). A Fracture Liaison Service (FLS) is an opportunity to evaluate the clinical relevance of these assays, in order to optimize patient care (19-21). Few studies exist about laboratory assays relevance in identifying secondary contributors in bone fragility (22-24), especially in elderly patients. None of these assessed the relevance of these blood tests when they are performed during the hospitalization for the fracture. This is an important point in the framework of the organization of the management of fragility after fracture.

The objective of this study was to assess the clinical relevance of early performed laboratory tests in identifying secondary causes of osteoporosis in a population with a recent low trauma non-vertebral fracture.

\section{Methods}

\subsection{Study design and population:}

In this prospective cohort study, patients older than 50 years old, hospitalized for a recent nonvertebral fracture, referred to our Fracture Liaison Service (FLS) from July 2015 to October 2016, were assessed for fracture risk assessment. They were included in the FLS during their hospitalization 
in the Orthopedic Department. Pathological fractures (metastatic cancer; myeloma) and high trauma fractures were exclusion criteria for inclusion in the FLS. The fracture risk assessment included risk factors assessment, performed once for each patient during the hospitalization after the surgery, and bone mineral density (BMD) measurement performed within three months after the fracture.

\subsection{Clinical data collection}

Clinical data were collected from declarative information and medical reports at the inclusion in FLS. Demographic data (age, gender, weight, height, body mass index), fracture type and date, history of previous fracture and other risk factors as family history of hip fracture, current smoking, excess of alcohol consumption ( $\geq 3$ units/day in man and $\geq 2$ units/day in woman), some comorbidities (diabetes, Parkinson disease, dementia, rheumatoid arthritis (based on the mention of the diagnosis in the medical file)), current or past use of corticosteroid (at a dose of prednisone-equivalent $>7.5 \mathrm{mg} / \mathrm{day}$ for at least 3 months), current or previous treatment with aromatases inhibitors, calcium and/or vitamin D supplementation, and previous anti-osteoporotic treatment (raloxifene, teriparatide, bisphosphonates and denosumab) in the year before the fracture were assessed.

\subsection{Bone densitometry and vertebral fracture assessment}

Bone mineral density (BMD) measurements were performed within 3 months using a single DXA device (Hologic QDR 4500 A Elite (Hologic, Bedford, MA)) at total hip, femoral neck, and lumbar spine. Osteoporosis was defined according to World Health Organization criteria, by a T-score $\leq-2.5$ at at least one site.

Vertebral fractures were identified with a Vertebral Fracture Assessment (VFA) acquisition performed at the same time of BMD measurement. Vertebral fractures were assessed from T4 to L4 with semiquantitative technique (25) by trained rheumatologists.

\subsection{Laboratory tests}


All measurements were performed in the same laboratory during the stay in the Orthopedics department, after surgery. Based on published data $(7,24,26)$, blood tests included hemoglobin, platelets, leukocytes, erythrocyte sedimentation rate or C-reactive protein, serum calcium (and calculation of corrected calcemia), serum inorganic phosphate, albumin, total serum alkaline phosphatases (ALP or TSALP), serum creatinine, intact plasma 1-84 parathormone (PTH), thyreostimulin (TSH); 25OH-vitamin D, serum protein electrophoresis. The estimated glomerular filtration rate (eGFR) was calculated using the modification of diet in renal disease study group (MDRD) equation. Stages of chronic kidney disease (CKD) were defined according to the guidelines for CKD of the National Kidney Foundation (27).

Results were considered abnormal when out of the range reported by the laboratory kits, except for the 25(OH)-vitamin D. According to French guidelines (28), serum $25(\mathrm{OH})$-vitamin D level of $75 \mathrm{nmol} / \mathrm{l}$ (30 ng/ml) or less was considered low and indicative of vitamin D insufficiency (29).

Elevated PTH was defined as a PTH level over the upper reference range $(\mathrm{PTH}>4.2 \mathrm{pmol} / \mathrm{L})$. Primary hyperparathyroidism was diagnosed with association of hypercalcemia (albumin corrected calcium 2.6 mmol/l) with an elevated or inappropriately value of serum PTH level. Elevated PTH without hypercalcemia was considered as secondary hyperparathyroidism.

Hyperthyroidism was defined by TSH values $0.4 \mathrm{mIU} / \mathrm{L}$ or less. Monoclonal gammapathy of undertermined significance (MGUS) was defined by the presence of M-protein in the serum without anaemia, hypercalcemia, kidney insufficiency and known bone lesions. Hypophosphatasemia was defined by total ALP rate under $35 \mathrm{UI} / \mathrm{L}$. Stage IV and V of chronic kidney disease assessed by an eGFR under $30 \mathrm{ml} / \mathrm{min}$, were reported.

\subsection{Statistical analysis}

We assessed proportions of patients with at least one biological abnormality (vitamin D insufficiency, biological hyperparathyroidism, hypercalcemia, hyperthyroidism biological hypophosphatasemia, monoclonal gammapathy, and stage IV and V of renal impairment) in the whole population, in men 
and women, in patients over 80 year-old, in patients with osteoporosis, and in patients with at least one vertebral fracture in VFA.

Results are presented as mean and standard deviation (SD) for quantitative variables, and as percentages and frequency for qualitative ones. The statistical analysis was carried out with $\mathrm{R}$ and Rstudio software. Chi ${ }^{2}$ test or exact Fischer's test were used when needed for comparison.

\section{Results}

Between July 2015 and October 2016, 439 patients were hospitalized for non-vertebral fractures. Sixty-seven patients were excluded, because their blood tests were not performed, due to the short duration of their hospitalization. Thus 372 patients with biological data (285 women and 87 men, mean age $77.5 \pm 13$ years) are the basis of this study (Table 1 ).

The majority of these fractured patients had hip fractures (69.8\%), with only 17 history of parental hip fracture. The other fractures leading to inclusion in the FLS were upper limb (20.5\%), lower limb $(17.8 \%)$. Sixteen (6.25\%) patients were receiving an anti-osteoporotic drug in the past year which was bisphosphonates for $75 \%$ of them. Twenty-nine $(8.2 \%)$ patients used corticosteroids $(>7.5 \mathrm{mg} / \mathrm{day}$ for at least 3 months) and 10 (2.9\%) patients used aromatase inhibitors.

Osteoporosis (T-score $\leq-2.5$ at least at one site) was identified in 109 patients (52.7\%). Using Vertebral Fracture Assessment, 59 (32.4\%) patients had at least one vertebral fracture which was unknown for the patient before the VFA.

\section{In the whole population}

Prevalence of patients with at least one biological abnormality in the whole population was $94.6 \%(\mathrm{n}=353)$. This prevalence was higher in men than in women ( $88 \%$ vs $76.9 \%, \mathrm{p} \leq 0.05)$. The most frequent abnormality was vitamin D insufficiency observed in $80 \%$ of patients $(\mathrm{N}=248)$. In patients receiving calcium and /or vitamin D supplementation, the prevalence of vitamin D insufficiency was 
$41.1 \%(\mathrm{~N}=107)$. The number of patients with serum $25 \mathrm{OH}$ vitamin $\mathrm{D}$ level below 50 and $25 \mathrm{nmol} / \mathrm{l}$ was $148(47.7 \%)$ and $67(21.6 \%)$ respectively. When vitamin D insufficiency was excluded, 287 (76.9\%) patients had at least one biological abnormality. 140 patients had several biological abnormalities (more than 2); 48 if we excluded vitamin D insufficiency.

Hypercalcemia was observed in $22(7.7 \%)$ patients. Among them, 6 patients had an increase in PTH with a profile of primary hyperparathyroidism. 16 patients had an appropriate decrease in PTH level. Hypercalcemia was asymptomatic and never above $3 \mathrm{mmol} / \mathrm{l}$. High value of serum PTH was found in $64(20.8 \%)$ patients. Among the 58 patients with secondary hyperparathyroidism, we identified 2 cases of CKD stage IV (eGFR $\leq 30 \mathrm{~mL} / \mathrm{min})$. Most of them (89\%) had a vitamin insufficiency (25 OH D $\leq$ $75 \mathrm{nmol} / \mathrm{L}$ ) and $39 \%$ a serum level of $25 \mathrm{OH} \mathrm{D} \leq 25 \mathrm{nmol} / \mathrm{L}$.

$41(13.8 \%)$ patients had serum TSH level below $0.4 \mathrm{mU} / \mathrm{L}, 3$ of them were previously known. Above the 314 electrophoresis performed, 81 abnormal gamma profiles were identified: hypogammaglobulinemia $(n=72,22.96 \%)$, polyclonal gammopathies $(n=6,1.9 \%)$, monoclonal bands $(\mathrm{n}=3,0.95 \%)$. Total alkaline phosphatase was low (ALP < $35 \mathrm{IU} / \mathrm{L})$ in $9(3.3 \%)$ patients with recent non-vertebral fracture.

\subsection{In the subgroups of population}

In the elderly group defined by an age of over 80 years (52.2\%), $90.7 \%$ had a serum $25 \mathrm{OH} \mathrm{D}$ $\leq 75 \mathrm{nmol} / \mathrm{L}, 49$ patients $(27.8 \%)$ had high serum PTH levels, 26 (15.1\%) had low TSH, and 18 (10.8\%) hypercalcemia. Only one patient had eGFR below $30 \mathrm{~mL} / \mathrm{min}$. If we compared them to patients $<80$ years, we found a higher prevalence of high serum PTH level $(27.8 \%$ vs $11.7 \%, \mathrm{p}=0.01)$ and of hypercalcemia $(10.8 \%$ vs $3.4 \%, \mathrm{p}<0.05)$ (Table 2$)$.

There was no difference in proportion of biological abnormalities, in patients with or without osteoporosis based on BMD measurements, and with or without vertebral fractures diagnosed on Vertebral Fracture Assessment (Table 2).

There was no difference in the frequency of biological abnormalities in patients with hip fractures (60.8\% of the population) as compared to non-hip / non-vertebral fracture (data not shown). 


\subsection{Discussion}

This study assessed clinical relevance of early performed laboratory tests in identifying secondary causes of osteoporosis in a population with a recent low trauma non-vertebral fracture. In these recent fractured patients, we found $94.6 \%$ of patients with at least one biological abnormality and that the most frequent abnormality was vitamin D insufficiency. If we excluded this abnormality, $76.9 \%$ patients had biological abnormalities that can contribute to bone fragility. Using Vertebral Fracture Assessment (VFA), we also confirmed the high proportion of patients with at least one unknown VF $(\mathrm{n}=59,32.4 \%)$, previously reported in other studies in patients with recent fracture (around 30\%) (30, 31), suggesting the need for vertebral fracture assessment in patients with non-vertebral fractures.

Our results confirmed the prevalence of abnormalities leading to secondary osteoporosis observed in other studies in patients with clinical fractures $(22,32)$ and in hip fractured patients, where $80 \%$ of patients had at least one abnormality (33). In younger patients with osteoporosis or a recent clinical fracture, the prevalence is reported lower, ranged from 26 to 51\% (34). The most frequent abnormality was vitamin D insufficiency, as expected (35), with no difference among patients with osteoporosis or with vertebral fractures. This prevalence was slightly higher in men ( $88 \%$ vs $76.9 \%)$ than in women, difference poorly reported in general or fractured populations $(36,37)$.

Insufficiency of vitamin D was the most frequent abnormality even if $41 \%$ of our patients were receiving vitamin $\mathrm{D}$ supplementation, suggesting that there was a discrepancy between given doses and serum values, or observance problems (38). As almost all patients have a vitamin D insufficiency, we justified the questionable performance of vitamin $\mathrm{D}$ assay with the difference between supplementation schemes (dose and rhythm of administration) to reach the recommended threshold according to baseline value. It was also justified because vitamin D insufficiency has to be corrected before the initiation of an anti-osteoporotic treatment. Moreover, the efficacy of anti-osteoporotic treatment is better if the vitamin D level is normal $(39,40)$.

Hyperparathyroidism and hyperthyroidism are known as metabolic disorders leading to bone loss (41-43) and should be research. We observed 64 (20.8\%) patients with high PTH level and 41 
(13.8\%) low TSH level. The prevalence of high serum PTH level was higher in men than in women (38.8\% vs $15.9 \%, \mathrm{p}<0.00001)$, and in older patients ( $\geq 80$ years) $(27.8 \%$ vs $11.7 \%, \mathrm{p}<0.01)$. Among them, six patients (1.9\%) had biological profiles compatible with primary hyperparathyroidism (PHPT). This result is close to that reported in patients with fracture (44).

The other explanation for elevated serum PTH was the vitamin D insufficiency, found in $90.3 \%$ of patients. Renal function impairment (eGFR $\leq 30 \mathrm{~mL} / \mathrm{min}$ ) was only found in 2 patients. However, serum PTH can increase a long time before patients reach late stages $(45,46)$.

High concentration of PTH can be due to a low intake of calcium, but calcium intake was not assessed. Finally some patients may have a normocalcemic primary hyperparathyroidism, more frequently diagnosed at an asymptomatic stage $(47,48)$. In non-referral men population, such as The Osteoporotic Fractures in Men (MrOS) study, normocalcemic hyperparathyroidism (PTH level over the upper reference range) was found in $9(0.4 \%)$ patients $(49,50)$, whereas in the Dallas Heart Study, 108 (3.1\%) patients had normocalcemic hyperparathyroidism with no difference between gender, with only $13(0.6 \%)$ persistent elevated PTH levels suggesting hyperparathyroidism $(49,51)$.

In our study, we found a high prevalence of hypercalcemia corrected on serum albumin but this may have been distorted by low rates of serum albumin in the acute post-operative context (stress, inflammation...). Even if acute disease is not the recommended timing to evaluate GFR (worsened by stress factors), we surprisingly only found in the population $2(0.59 \%)$ patients with eGFR under 30mL/min (MDRD), 43 (12.7\%) with eGFR < 60mL/min (MDRD) and $14(11 \%)$ eGFR $<30 \mathrm{~mL} / \mathrm{min}$ (Cockcroft-Gault), 12 of them over 80 year-old (123 patients). The MDRD equation underestimates mean eGFR by $25 \%$. This bias may lead to misclassifying healthy older persons as having CKD (52). The expected prevalence of CKD $\left(<60 \mathrm{~mL} / \mathrm{min} / 1.73 \mathrm{~m}^{2}\right)$ is $37.1 \%$ using the MDRD equation and 55.9\% using the Cockcroft-Gault equation. In studies with measured (not estimated) GFR by iohexol clearance, this prevalence was $48.8 \%$ (>70 years), and it ranged from $33.2 \%$ ([70;74] years) to $91.4 \%$ (>90 years) $(53)$

In the 41 patients with low TSH level, 6 patients had TSH level under $0.1 \mathrm{mU} / \mathrm{L}$ (and no story of thyroid disease known). No difference in gender, in age status, BMD status and presence of vertebral fracture was shown. It is known that even subclinical hyperthyroidism is associated with an increased 
risk of hip fractures, particularly among those with TSH levels of less than $0.10 \mathrm{mIU} / \mathrm{L}$ (54). TSH levels are commonly lower and negatively related to age $(55,56)$. However, in elderly patients with TSH between 0.1 and $0.4 \mathrm{IU} / \mathrm{L}$, progression to clinical hyperthyroidism remains rare (approximately $1 \%$ per year) and spontaneous TSH normalization is fairly common (57). TSH level is reported to be associated with many acute situations (pancreatitis, coronary syndrome, liver failure, depression...) and this can be finally the explanation to high TSH. (58-61).

Abnormal gammaglobulin level was observed in 81 serum protein electrophoresis with hypogammaglobulinemia $(\mathrm{n}=72,22.7 \%)$, polyclonal gammopathies $(\mathrm{n}=6,1.9 \%)$ and monoclonal bands $(n=3,0.9 \%)$. All monoclonal bands occurred in patients with hip fracture, and one had a so far unknown vertebral fracture detected on VFA. MGUS frequency is known higher in patients with vertebral fractures (12). We did not find any multiple myeloma, probably due to the exclusion of pathological fractures. Our results lead us to discuss the value of this assay in the case of a low trauma non-vertebral fracture for whose pathological cause has been excluded.

Our hypogammaglobulinemia can be explained by the acute ill state of patients as altered plasma immunoglobulin concentrations were decreased in sepsis or other situation of systemic inflammation (62).

Among the 9 patients with hypophosphatasemia (ALP <35 IU/L), none were receiving anti-resorptive treatments. As far as we know during the follow-up, none of these abnormalities was persistent suggesting transient hypophosphatasia due to perioperative stress (63).

Frequencies of biological abnormalities were not different with or without osteoporosis . Furthermore, we did not find any difference in the proportion of abnormalities in patients with previous prevalent VFs.

One relevant remaining question is the better timing to perform these blood tests in a patient with a recent fracture. Our study showed that if they are performed very early just after the fracture, there is high proportion of abnormalities that needs to be checked later during the follow-up, delaying the start of an anti-osteoporotic treatment. However, in the FLS model, the recommendation is to introduce an anti-osteoporotic therapy in the 3 months after the fracture (3). Though, if blood tests are performed later, the check and the corrections of some abnormalities, such as vitamin D insufficiency, delay the 
introduction of antiosteoporotic treatment. Our suggestion is to perform these tests later, for example at one month after the fracture, with a risk of losing patients to follow-up. The choice of the best time to carry out these tests to remove another cause of bone fragility remains an essential point in post fracture management care.

One of the study's strength was the systematic blood tests, decreasing the number of lost to follow-up patients in this osteoporosis population. One limit was the cross-sectional design where no follow-up was available for this study. Nevertheless, the patients were followed by their general practitioner and the rheumatologist involved in the FLS.

This study performed in patient with recent low trauma non vertebral fractures showed that $94.6 \%$ of patients had at least one contributor to bone fragility, which was the vitamin D insufficiency in the great majority of cases. We found a high proportion of biological abnormalities which require additional explorations but most of them can be explained by the postoperative context. Performing the blood tests early after the fracture leads to a high rate of abnormalities that need to be checked later. Appropriate time to perform these biological exams, without delaying the introduction of antiosteoporotic treatment remains to be determined.

\section{Disclosure of interest}

The authors declare that they have no competing interest.

\section{Funding and research grant}

We did not receive any funding or research grants for this study. 


\section{REFERENCES}

1. Bliuc D, Nguyen ND, Milch VE, Nguyen TV, Eisman JA, Center JR. Mortality risk associated with low-trauma osteoporotic fracture and subsequent fracture in men and women. JAMA 2009;301:513-21.

2. Center JR, Bliuc D, Nguyen TV, Eisman JA. Risk of subsequent fracture after low-trauma fracture in men and women. JAMA. 24 janv 2007;297:387-94.

3. Eisman JA, Bogoch ER, Dell R, et al. Making the first fracture the last fracture: ASBMR task force report on secondary fracture prevention. J Bone Miner Res 2012;27:2039-46.

4. Briot K, Cortet B, Thomas T, et al. 2012 update of French guidelines for the pharmacological treatment of postmenopausal osteoporosis. Joint Bone Spine 2012;79:304-13.

5. Compston J. NOGG and NICE: New guidelines and quality standards for osteoporosis. Maturitas2017;106:97-8.

6. Compston J, Bowring C, Cooper A, et al. Diagnosis and management of osteoporosis in postmenopausal women and older men in the UK: National Osteoporosis Guideline Group (NOGG) update 2013. Maturitas. 2013;75:392-6.

7. Compston J, Cooper A, Cooper C, et al. UK clinical guideline for the prevention and treatment of osteoporosis. Arch Osteoporos 2017;12:43.

8. Compston J. US and UK guidelines for glucocorticoid-induced osteoporosis: similarities and differences. Curr Rheumatol Rep. 2004;6:66-9.

9. Javaid MK, Kyer C, Mitchell PJ, et al. Effective secondary fracture prevention: implementation of a global benchmarking of clinical quality using the IOF Capture the Fracture ${ }^{\circledR}$ Best Practice Framework tool. Osteoporos Int J Establ Result Coop Eur Found Osteoporos Natl Osteoporos Found USA2015;26:2573-8.

10. Ebeling PR. Clinical practice. Osteoporosis in men. N Engl J Med 2008;358):1474-82.

11. Khosla S, Amin S, Orwoll E. Osteoporosis in men. Endocr Rev 2008;29:441-64. 
12. Bida JP, Kyle RA, Therneau TM, , et al. Disease associations with monoclonal gammopathy of undetermined significance: a population-based study of 17,398 patients. Mayo Clin Proc. 2009;84:685-93.

13. Veronese N, Luchini C, Solmi M, Sergi G, Manzato E, Stubbs B. Monoclonal gammopathy of undetermined significance and bone health outcomes: a systematic review and exploratory metaanalysis. J Bone Miner Metab. 2018;36:128-32.

14. Piot JM, Royer M, Schmidt-Tanguy A, et al. Factors associated with an increased risk of vertebral fracture in monoclonal gammopathies of undetermined significance. Blood Cancer $\mathrm{J}$. 2015;5:e345.

15. Khosla S, Melton 3rd J. Fracture risk in primary hyperparathyroidism. J Bone Miner Res Off J Am Soc Bone Miner Res.2002;17:N103-7.

16. Vignali E, Viccica G, Diacinti D, et al. Morphometric Vertebral Fractures in Postmenopausal Women with Primary Hyperparathyroidism. J Clin Endocrinol Metab. 2009;94:2306-12.

17. Kenny AM, MacGillivray DC, Pilbeam CC, Crombie HD, Raisz LG. Fracture incidence in postmenopausal women with primary hyperparathyroidism. Surgery. 1995;118:109-14.

18. Stein EM, Silva BC, Boutroy S, et al. Primary hyperparathyroidism is associated with abnormal cortical and trabecular microstructure and reduced bone stiffness in postmenopausal women. J Bone Miner Res. 2013;28:1029-40.

19. McLellan AR, Gallacher SJ, Fraser M, McQuillian C. The fracture liaison service: success of a program for the evaluation and management of patients with osteoporotic fracture. Osteoporos Int $\mathbf{J}$ Establ Result Coop Eur Found Osteoporos Natl Osteoporos Found USA. 2003;14:1028-34.

20. Briot K. Fracture Liaison Services. Curr Opin Rheumatol. 2017;29:416-21.

21. Huntjens KMB, van Geel TACM, van den Bergh JPW, et al. Fracture liaison service: impact on subsequent nonvertebral fracture incidence and mortality. J Bone Joint Surg Am. 2014;96:e29.

22. Bogoch ER, Elliot-Gibson V, Wang RYC, Josse RG. Secondary causes of osteoporosis in fracture patients. J Orthop Trauma. 2012;26:e145-152. 
23. Bours SPG, van Geel TACM, Geusens PPMM, et al. Contributors to secondary osteoporosis and metabolic bone diseases in patients presenting with a clinical fracture. J Clin Endocrinol Metab 2011;96:1360-7.

24. Tannenbaum C, Clark J, Schwartzman K, et al. Yield of laboratory testing to identify secondary contributors to osteoporosis in otherwise healthy women. J Clin Endocrinol Metab. $2002 ; 87: 4431-7$

25. Genant HK, Wu CY, van Kuijk C, Nevitt MC. Vertebral fracture assessment using a semiquantitative technique. J Bone Miner Res Off J Am Soc Bone Miner Res. 1993;8:1137-48.

26. Dumitrescu B, van Helden S, ten Broeke R, et al. Evaluation of patients with a recent clinical fracture and osteoporosis, a multidisciplinary approach. BMC Musculoskelet Disord. 2008;9:109.

27. KDIGO working group: Introduction and definition of CKD-MBD and the development of the guideline statments. Kidney Int. 2009;79:S3-8.

28. La vitamine D chez l'adulte : recommandations du GRIO. Presse Médicale 2011;40:673-82.

29. Briot K, Roux C, Thomas T, Blain H, et al. 2018 update of French recommendations on the management of postmenopausal osteoporosis. Jt Bone Spine Rev Rhum. 11 avr 2018;

30. Vranken L, Wyers CE, van den Bergh JPW, Geusens PPMM. The Phenotype of Patients with a Recent Fracture: A Literature Survey of the Fracture Liaison Service. Calcif Tissue Int. 2017 ;101:248-258. doi: 10.1007/s00223-017-0284-1.

31. van der Velde RY, Bours SPG, Wyers CE, Lems WF, Geusens PPMM, van den Bergh JPW, Effect of implementation of guidelines on assessment and diagnosis of vertebral fractures in patients older than 50 years with a recent non-vertebral fracture. Osteoporos Int. 2017;28:3017-3022. doi: 10.1007/s00198-017-4147-4. 32. Bours SPG, van den Bergh JPW, van Geel TACM, Geusens PPMM. Secondary osteoporosis and metabolic bone disease in patients 50 years and older with osteoporosis or with a recent clinical fracture: a clinical perspective. Curr Opin Rheumatol.2014;26:430-9.

33. Edwards $\mathrm{MH}$, Jameson $\mathrm{K}$, Denison $\mathrm{H}$, et al. Clinical risk factors, bone density and fall history in the prediction of incident fracture among men and women. Bone. 2013;52:541-7. 
34. LeBoff MS, Kohlmeier L, Hurwitz S, Franklin J, Wright J, Glowacki J. Occult vitamin D deficiency in postmenopausal US women with acute hip fracture. JAMA. 1999;281:1505-11.

35. Dawson-Hughes B, Mithal A, Bonjour J-P, et al. IOF position statement: vitamin D recommendations for older adults. Osteoporos Int J Establ Result Coop Eur Found Osteoporos Natl Osteoporos Found USA. 2010;21:1151-4.

36. Hicks GE, Shardell M, Miller RR, et al. Associations Between Vitamin D Status and Pain in Older Adults: The Invecchiare in Chianti Study. J Am Geriatr Soc. 2008;56:785-91.

37. Wingfield T, Schumacher SG, Sandhu G, et al. The Seasonality of Tuberculosis, Sunlight, Vitamin D, and Household Crowding. J Infect Dis. 2014;210:774-83.

38. Simonelli C, Weiss TW, Morancey J, Swanson L, Chen Y-T. Prevalence of vitamin D inadequacy in a minimal trauma fracture population. Curr Med Res Opin. 2005;21:1069-74.

39. . Bischoff-Ferrari HA, Willett WC, Orav EJ, et al. A pooled analysis of vitamin D dose requirements for fracture prevention. N Engl J Med. 2012;367:40-9.

40. Bischoff-Ferrari HA, Willett WC, Wong JB, Giovannucci E, Dietrich T, Dawson-Hughes B. Fracture prevention with vitamin D supplementation: a meta-analysis of randomized controlled trials. JAMA. 2005;293:2257-64.

41. Silverberg SJ, Gartenberg F, Jacobs TP, et al. Longitudinal measurements of bone density and biochemical indices in untreated primary hyperparathyroidism. J Clin Endocrinol Metab. 1995;80:723 -8 .

42. Rosen CJ, Adler RA. Longitudinal changes in lumbar bone density among thyrotoxic patients after attainment of euthyroidism. J Clin Endocrinol Metab. 1992;75:1531-4.

43. Mundy GR, Shapiro JL, Bandelin JG, Canalis EM, Raisz LG. Direct stimulation of bone resorption by thyroid hormones. J Clin Invest. 1976;58:529-34.

44. Malgo F, Appelman-Dijkstra NM, Termaat MF, et al. High prevalence of secondary factors for bone fragility in patients with a recent fracture independently of BMD. Arch Osteoporos. 2016;11:12. 
45. O'Flaherty D, Sankaralingam A, Scully P, Manghat P, Goldsmith D, Hampson G. The relationship between intact PTH and biointact PTH (1-84) with bone and mineral metabolism in predialysis chronic kidney disease (CKD). Clin Biochem 2013;46:1405-9.

46. Moranne O, Froissart M, Rossert J, et al. Timing of Onset of CKD-Related Metabolic Complications. J Am Soc Nephrol. 2009;20:164-71.

47. Abood A, Vestergaard P. Increasing incidence of primary hyperparathyroidism in Denmark. Dan Med J. 2013;60:A4567.

48. Yu N, Donnan PT, Flynn RWV, et al. Increased mortality and morbidity in mild primary hyperparathyroid patients. The Parathyroid Epidemiology and Audit Research Study (PEARS). Clin Endocrinol (Oxf). 2010;73:30-4.

49. Cusano NE, Maalouf NM, Wang PY, et al. Normocalcemic Hyperparathyroidism and Hypoparathyroidism in Two Community-Based Nonreferral Populations. J Clin Endocrinol Metab. 2013;98:2734-41.

50.. Blank JB, Cawthon PM, Carrion-Petersen ML, et al. Overview of recruitment for the osteoporotic fractures in men study (MrOS). Contemp Clin Trials. 2005;26:557-68.

519. Bauer DC, Garnero P, Harrison SL, et al. Biochemical markers of bone turnover, hip bone loss, and fracture in older men: the MrOS study. J Bone Miner Res Off J Am Soc Bone Miner Res 2009;24:2032-8.

52. Nitta K, Okada K, Yanai M, Takahashi S. Aging and chronic kidney disease. Kidney Blood Press Res. 2013;38:109-20.

53. Delanaye P, Melsom T, Ebert N, et al. Iohexol plasma clearance for measuring glomerular filtration rate in clinical practice and research: a review. Part 2: Why to measure glomerular filtration rate with iohexol? Clin Kidney J. 2016;9:700-4.

54. Blum MR, Bauer DC, Collet T-H, et al. Subclinical thyroid dysfunction and fracture risk: a meta-analysis. JAMA. 2015;313:2055-65. 
55. Hollowell JG, Staehling NW, Flanders WD, et al. Serum TSH, T 4 , and Thyroid Antibodies in the United States Population (1988 to 1994): National Health and Nutrition Examination Survey (NHANES III). J Clin Endocrinol Metab 2002;87):489-99.

56. Laurberg P, Cerqueira C, Ovesen L, et al. Iodine intake as a determinant of thyroid disorders in populations. Best Pract Res Clin Endocrinol Metab. 2010;24:13-27.

57. Rosario PW. Natural history of subclinical hyperthyroidism in elderly patients with TSH between 0•1 and 0•4 mIU/l: a prospective study. Clin Endocrinol (Oxf). 2010;72:685-8.

58. Yang N, Zhang D-L, Hao J-Y, Wang G. Serum levels of thyroid hormones and thyroid stimulating hormone in patients with biliogenic and hyperlipidaemic acute pancreatitis: Difference and value in predicting disease severity. J Int Med Res. 2016;44:267-77.

59. $\mathrm{Wu} \mathrm{Y,} \mathrm{You} \mathrm{S,} \mathrm{Zang} \mathrm{H,} \mathrm{et} \mathrm{al.} \mathrm{Usefulness} \mathrm{of} \mathrm{serum} \mathrm{thyroid-stimulation} \mathrm{hormone} \mathrm{(TSH)} \mathrm{as} \mathrm{a}$ prognostic indicator for acute-on-chronic liver failure. Ann Hepatol. 2015;14:218-24.

60. Viswanathan G, Balasubramaniam K, Hardy R, Marshall S, Zaman A, Razvi S. Blood thrombogenicity is independently associated with serum TSH levels in post-non-ST elevation acute coronary syndrome. J Clin Endocrinol Metab. 2014;99:E1050-1054.

61. Wysokiński A, Kłoszewska I. Level of thyroid-stimulating hormone (TSH) in patients with acute schizophrenia, unipolar depression or bipolar disorder. Neurochem Res 2014;39:1245-53.

62. Shankar-Hari M, Culshaw N, Post B, et al. Endogenous IgG hypogammaglobulinaemia in critically ill adults with sepsis: systematic review and meta-analysis. Intensive Care Med. 2015;41:1393-401.

63. McKiernan FE, Shrestha LK, Berg RL, Fuehrer J. Acute hypophosphatasemia. Osteoporos Int. 2014;25:519-23. 
Table 1: Characteristics of the population

\begin{tabular}{|c|c|}
\hline Variables & \\
\hline Age (years, mean \pm sd) & $77.5 \pm 13$ \\
\hline BMI $\left(\mathrm{kg} / \mathrm{m}^{2}\right.$, mean $\left.\pm \mathrm{sd}\right)$ & $23.9 \pm 5.2$ \\
\hline Menopause (years, mean \pm sd) & $49.5 \pm 4.5$ \\
\hline Dementia $(\mathrm{n}, \%)$ & $95(27.7)$ \\
\hline Parkinson $(\mathrm{n}, \%)$ & $16(4.7)$ \\
\hline Diabetes $(\mathrm{n}, \%)$ & $43(12.1)$ \\
\hline Hyperthyroidism (n,\%) & $11(3.1)$ \\
\hline Rheumatoid arthritis (n,\%) & $8(2.25)$ \\
\hline Use of walking assistance $(\mathrm{n}, \%)$ & $107(30.7)$ \\
\hline Current smoking $(\mathrm{n}, \%)$ & $55(15.5)$ \\
\hline Excess of Alcohol consumption $(\mathrm{n}, \%)$ & $27(7.65)$ \\
\hline Parental Hip Fracture (n, \%) & $28(12.1)$ \\
\hline Fall $(\mathrm{n}, \%)$ & $257(92.3)$ \\
\hline Corticosteroids use (n, \%) & $29(8.2)$ \\
\hline Selective serotonin inhibitor use $(\mathrm{n}, \%)$ & $37(11)$ \\
\hline Antiaromatase inhibitors use (n, \%) & $10(3)$ \\
\hline Vitamin D supplementation (n, \%) & $107(41.5)$ \\
\hline Anti Osteoporotic treatment use (n, \%) & $15(5.9)$ \\
\hline \multicolumn{2}{|l|}{ Biological markers (mean $\pm \mathrm{sd}$ ) } \\
\hline Corrected. Calcemia (mmol/L) & $2.44 \pm 0.12$ \\
\hline Serum creatinine $(\mu \mathrm{mol} / \mathrm{L})$ & $70.3 \pm 29.9$ \\
\hline Total ALP (IU/L) & $79.6 \pm 90.5$ \\
\hline $\mathrm{PTH}(\mathrm{pmol} / \mathrm{L})$ & $3.26 \pm 1.9$ \\
\hline TSH (mU/L) & $2.01 \pm 6.9$ \\
\hline $25 \mathrm{OH}$ vit.D (nmol/L) & $54.5 \pm 32.5$ \\
\hline Serum Albumin $(g / L)$ & $32.1 \pm 4.7$ \\
\hline
\end{tabular}

BMI Body mass Index; ALP: alkaline phosphatase; PTH: parathormone; TSH thyreostimulin 
Table 2. Results on biological abnormalities in total and subgroups of population.

\begin{tabular}{|c|c|c|c|c|c|c|c|c|c|c|c|c|c|}
\hline \multirow[b]{2}{*}{ Abnormality: n (\%) } & \multirow[t]{2}{*}{ TOTAL } & \multicolumn{3}{|c|}{ GENDER } & \multicolumn{3}{|c|}{$\overline{\text { AGE }}$} & \multicolumn{3}{|c|}{ T-SCORE } & \multicolumn{3}{|c|}{ Vertebral fracture } \\
\hline & & Women & Men & $p$-value & $\geq 80$ & $<80$ & $p$ & $\leq-2.5$ & $>-2.5$ & $p$ & $\geq 1$ & $<1$ & $p$ \\
\hline vitamin $D \leq 75 \mathrm{nmol} / \mathrm{L}$ & $248(80)$ & $183(76.9)$ & $64(88.8)$ & 0.04 & $176(98.8)$ & $132(99)$ & 1 & $74(79.6)$ & $70(79.5)$ & 1 & $44(83)$ & $84(78.5)$ & 0.64 \\
\hline$P T H>4.2 \mathrm{pg} / \mathrm{mL}$ & $64(20.8)$ & 37 (15.9) & $28(38.8)$ & $<0.0001$ & $49(27.8)$ & 15 (11.7) & 0.013 & $23(25.5)$ & $11(12.9)$ & 0.06 & $14(27.5)$ & $18(16.9)$ & 0.19 \\
\hline$T S H<0.4 \mathrm{mU} / \mathrm{L}$ & $41(13.8)$ & $30(13.3)$ & $11(15.5)$ & 0.06 & $26(15.1)$ & $15(12.2)$ & 0.59 & $15(16.6)$ & 9 (11.4) & 0.47 & $5(10.4)$ & $15(14.7)$ & 0.64 \\
\hline Calcium $>2.6 \mathrm{mmol} / \mathrm{L}$ & $22(7.7)$ & $18(8.3)$ & $4(5.88)$ & 0.61 & $18(10.8)$ & $4(3.41)$ & 0.038 & $9(10.8)$ & $5(6.34)$ & 0.46 & $4(8.3)$ & $8(8.4)$ & 1 \\
\hline Total ALP < 35UI / L & $9(3.3)$ & $6(2.9)$ & $3(4.4)$ & 0.69 & $3(1.85)$ & $6(5.3)$ & 0.17 & $3(3.79)$ & $5(6.67)$ & 0.48 & $2(4.2)$ & $5(5.5)$ & 1 \\
\hline Monoclonal Band & $3(0.8)$ & $3(1.25)$ & 0 & 1 & $2(1.5)$ & $1(0.55)$ & 1 & $1(1.1)$ & $2(2.32)$ & 1 & $1(1.9)$ & $1(0.97)$ & 1 \\
\hline$e G F R<30 \mathrm{~mL} / \mathrm{min}$ & $2(0.6)$ & $1(0.4)$ & $1(1.2)$ & 0.43 & $1(0.53)$ & $1(0.68)$ & 1 & $1(1)$ & $1(1.1)$ & 1 & 0 & $2(1.8)$ & 1 \\
\hline
\end{tabular}

$V F$ : vertebral Fracture. Age class (years). PTH : parathormone. TSH: Thyreostimulin. ALP: alkaline phosphatase. eGFR : estimated glomerular filtration rate. 